\title{
HUMAN RIGHTS, “ARRANGED” MARRIAGES AND FAMILY LAW: SHOULD CULTURE OVERRIDE OR INFORM FRAUD AND DURESS?
}

\author{
Jocelynne A Scutt*
}

\begin{abstract}
Family law in Australia and Fiji provides that marriages can be void on various grounds, including duress and fraud. Despite some differences, United Kingdom (UK) law says marriages can be void or voidable on similar grounds. Courts in each jurisdiction have granted annulment in cases of forced marriage where duress "threatens life and limb". Courts now say lesser force or threats, including pressure to comply with religious or traditional duty, can nullify marriage. Yet courts continue to require high level force such as passport confiscation, physical abuse, threats of eviction from the family home, and economic harm. This, as with allegations of fraud which receive short shrift, results from returning to common law authorities decided before migration resulted in significant demographic changes, particularly regarding culture and religion. UK authority draws a distinction between "forced" and "arranged" marriages, saying nullity is granted rightly in cases of the former, yet because "culture" "sanctifies" the latter, refusing nullity is right. Yet is this distinction valid? Should such marriages be recognised by Australian, Fijian and UK courts as contracted with full and free consent of the parties? An exploration of contemporary cases against the common law background to fraud and duress as nullity grounds indicates that allowing culture to be the measure denies women's (and sometimes men's) entitlement to contract marriage with full and free consent according to international human rights law.
\end{abstract}

\section{INTRODUCTION}

In April 2013, Pakistan's Sindh Province passed the Child Marriage Restraint Act criminalising marriages of girls under 18 years of age. ${ }^{1}$ Earlier, in March 2011, the German Bundestag approved a law imposing

\footnotetext{
* The Hon Dr Jocelynne A Scutt, Barrister and Human Rights Lawyer, Visiting Professor and Senior Fellow, the University of Buckingham.

${ }^{1}$ See further below.
} 
five years imprisonment upon any person convicted of forcing another into marriage. ${ }^{2}$ Germany, along with Austria, the Netherlands and prospectively Belgium, also imposed a minimum age for marriage visas. So did the UK. Later (in 2014) forcing someone into marriage in England and Wales or forcing a British national into marriage outside the UK became unlawful, carrying a seven-year maximum penalty. ${ }^{3}$ However, the UK visa requirement came under challenge. In October 2011, the Supreme Court in $R$ (on the application of Quila and another) (FC)(Respondents) $v$ Secretary of State for the Home Department (Appellant) ${ }^{4}$ struck down paragraph 277 of the Immigration Rules banning entry for settlement of foreign spouses or civil partners unless both were 21 years or above.

\section{ENGLAND \& WALES CASES}

These criminal and civil law measures were intended to combat forced marriage. Generally, the problem is understood as having become acute in Western countries with increased migration from countries where culture, religion and tradition are perceived to play a major role in selection of marriage partners for reasons other than "love match" or "acceptable" arrangement. ${ }^{5}$ With forced marriage, choice is not open to the parties. In Quila $^{6}$ the Secretary of State advanced the sole purpose of the Rule as being to deter or prevent forced marriage. The Rule provided that no partner or prospective partner under 21 years of age would be issued with a marriage visa, namely entry clearance, leave to enter, leave to remain or variation of leave on marriage grounds. The Supreme Court considered a

2 'Penalties for Forced Marriages: Berlin Passes New Integration Measure', SpiegelOnline (18 March 2011),

$<$ http://www.spiegel.de/international/germany/penalties-for-forced-marriageberlin-passes-new-integration-measures-a-7517409.html> accessed 21 March 2011.

${ }^{3}$ Anti-social Behaviour, Crime and Policing Act 2014 (UK), ss 121 and 122. ${ }^{4}$ [2011] UKSC 45.

${ }^{5}$ Quila (ibid (n 4)) [9] (Lord Wilson) puts the 'prevalence of forced marriage within sections of' the UK community as coming 'increasingly to the attention of a shocked public' over the preceding 12 years 'as victims of it, or witnesses to it, have at least and less infrequently summoned the courage to report it'. The 1999 date is referable to the Home Office having established in that year a Forced Marriage Working Group. "Arranged” marriages are seen as acceptable, a distinction being drawn between the latter and forced marriages. See further this article.

${ }^{6}$ [2011] UKSC 45. 
legitimate aim under Article 8 of the European Convention on Human Rights (ECHR) "for the rights and freedoms of others" to be "preventing, deterring or delaying" forced marriages. Yet was the Rule necessary in a democratic society as a proportionate response to a pressing social need? ${ }^{7}$ Wilson LJ adopted Bingham LJ's Huang $v$ Secretary of State for the Home Department ${ }^{8}$ formula:

a) is the legislative objective sufficiently important to justify limiting a fundamental right?

b) are the measures designed to meet it rationally connected to it?

c) are they no more than necessary to accomplish it?

d) do they strike a fair balance between the rights of the individual and the interests of the community? ${ }^{9}$

The majority (Brown LJ dissenting) ${ }^{10}$ determined the Rule as incompatible with Article 8. Hale LJ identified three bases for offending against proportionality:

- interfering with "many more entirely voluntary marriages" than preventing, deterring or delaying forced marriages, the Secretary of State "scarcely [having] considered ... the scale and severity of the impact upon these unforced marriages"; 11

- an "entire lack of clarity" whether the rule had the "desired effect upon the marriages it [was] designed to prevent or deter"; ${ }^{12}$ and

- the Rule "may do a great deal more harm than good" for "A young woman may be sent abroad and forced to marry against her will and kept there until she can sponsor her husband to [the United Kingdom]. During this time she may be raped many times, bear children she does not want to have and be deprived of the education and life she would otherwise have had [in the UK] ..."13

Albeit addressing immigration law, $R$ (Quila and another) $v$ Secretary of State is instructive when it comes to nullity of forced marriages.

\footnotetext{
${ }^{7}$ Quila (ibid (n 4)) [45] (Lord Wilson), [73] (Lady Hale).

8 [2007] 2 AC 167.

${ }^{9}$ Quila (ibid (n 4)) [49] (Lord Wilson).

${ }^{10}$ Ibid [81]-[97].

${ }^{11}$ Ibid [74].

12 Ibid.

${ }^{13}$ Ibid [75].
} 


\section{FORCED AND ARRANGED MARRIAGES}

The Family Law Act 1996 (EW) addresses this at point of marriage: s 63Q

Shortly after issuing Rule 8, the Secretary of State published a guide to forced marriage, identifying "some of the key motives", said to include:

- Controlling unwanted sexuality (including perceive promiscuity, or being lesbian, gay, bisexual or transgender) - particular the behaviour and sexuality of women.

- Controlling unwanted behaviour, for example, alcohol and drug use, wearing make-up or behaving in a "westernised manner".

- Preventing "unsuitable" relationships, for example, outside the ethnic, cultural, religious or caste group.

- Protecting “family honour" or "izzat”.

- Responding to peer group or family pressure.

- Attempting to strengthen family links.

- Achieving financial gain.

- Ensuring land, property and wealth remain within the family.

- Protecting perceived cultural ideals.

- Protecting perceived religious ideals which are misguided.

- Ensuring care for a child or vulnerable adult with special needs when parents or existing carers are unable to fulfil that role.

- Assisting claims for UK residence and citizenship.

- Long-standing family commitments. ${ }^{14}$

In England and Wales, a distinction is drawn between forced and arranged marriages, the latter being acceptable, the former not. ${ }^{15}$ Acceptability is spelled out by Wilson LJ in Quila as where one party

\footnotetext{
14 Ibid [76].

15 See Forced Marriage Unit (FMU), Forced Marriage: A Wrong Not a Right Summary of Responses to the Consultation on the Criminalisation of Forced Marriage (Foreign \& Commonwealth Office, London, UK); Home Office, A Choice By Right - The Report of the Working Group on Forced Marriage (London, 2000); Centre LGS, Response to the Home Office Consultation Document - 'Forced Marriage: A Wrong Not A Right', ANRC Research Centre for Law, Gender and Sexuality, London, UK, November 2005; UK Parliament, 'Forced Marriage (Civil Protection) Bill [HL]', Hansard - House of Lords, 26 January 2007, pp 1-5,

<http://www.publications.parliament.uk/pa/pabills/200607/forced_marriage_civil _protection.htm> accessed 14 April 2014.
} 
enters "not only without her or his free and full consent but also as a result of force including coercion by threats or by other psychological means", citing ss 63A (4) and (6) Family Law Act 1996, inserted by s 1 of the Forced Marriage (Civil Protection) Act 2007. ${ }^{16}$ Further, a forced marriage is "entirely different" from an arranged marriage where "in conformity with their cultural expectations, two persons consent to marry pursuant to an arrangement negotiated between their respective families". ${ }^{17}$ Next, referring to the Universal Declaration of Human Rights (UDHR) 1948: Article 16(2), International Covenant on Civil and Political Rights (ICCPR) 1966, Article 23(3) and ECHR, Article 12, Wilson LJ said forced marriage is a "gross and abhorrent violation" of rights. ${ }^{18}$

Apart from the ECHR, these, along with other international instruments, refer to free consent to marry. The UDHR affirms "free and full consent of the intending spouses", ${ }^{19}$ which the ICCPR reiterates (Article 23), adding the "right of men and women of marriageable age to marry". ${ }^{20}$ Albeit not referred to, Article 16(1)(b) of the Convention on the Elimination of All Forms of Discrimination Against Women (CEDAW) insists on a "basis of equality of men and women", with free choice of spouse and "full and free consent". ${ }^{21}$ The CEDAW Committee's General Recommendation 21 specifically affirms women's rights of spousal choice and entering marriage freely as "central to her life and her dignity and equality as a human being". ${ }^{22}$ Meanwhile, the International Covenant on Economic, Social and Cultural Rights (ICESCR) Article 10 says marriage "must be entered into with the free consent of the intending spouses ..." ${ }^{23}$ Curiously, the ECHR refers (Article 12) to the UDHR, yet omits reference to consent or choice, potentially sanctioning state laws countenancing marriage without free consent: "Men and women of

\footnotetext{
${ }^{16}$ Quila (ibid (n 4)) [9].

${ }^{17}$ Ibid.

18 Ibid.

19 UDHR 1948, <http://www.un.org/en/documents/udhr/> accessed 21 April 2014.

20 ICCPR 1966 <http://www.ohchr.org/en/professionalinterest/pages/ccpr.aspx>
} accessed 21 April 2014.

21 CEDAW 1979, <http://www.un.org/womenwatch/daw/cedaw/> accessed 21 April 2014.

22 CEDAW Committee, General Recommendation No 21 (13 ${ }^{\text {th }}$ session 1994), 'equality in marriage and family relations' [16], $<$ http://www.un.org/womenwatch/daw/cedaw/recommendations/recomm.htm\#rec om21> accessed 21 April 2014.

${ }^{23}$ ICESCR 1966,

$<$ https://treaties.un.org/pages/viewdetails.aspx?chapter=4\&lang=en\&mtdsg_no=i v-3\&src=treaty $>$ accessed 21 April 2014. 
marriageable age have the right to marry and to found a family, according to the national laws governing the exercise of this right." 24

It is also curious that arranged marriages are not seen to contradict full and free consent. Wilson LJ cites cultural expectations in conjunction with consent, as if culture or cultural imperatives remove a marriage from possible force or lack of consent. Yet the ICESCR explicitly mandates intending spouses' free consent. Further, many marriages are arranged in conformity with the Secretary of State's indicators for forced marriages.

Notably, Wilson LJ sees forced marriages as not only denoting lack of free and full consent but having an additional factor of force, ${ }^{25}$ defined as including coercion by threats or by other psychological means. Yet none of the international instruments referring to marriage by consent says or implies lack of its full and free or free character must be by force, whether of the nature contemplated by Wilson LJ or not. Wilson LJ seems to posit two steps: prove lack of free and full consent; prove force and coercion, as if somehow the two are separate and distinct rather than necessarily part and parcel of the same design or proof. Surely force and coercion are not additional to a lack of full and free consent, but are what can make consent neither full nor free. Further, if an arrangement is negotiated by persons not being the parties to the marriage, this should at least raise a question - even a doubt - whether consent is full and freely given. Is consent in such circumstances real, or at least a query as to its reality required?

Family law encapsulates these issues. That a distinction can be drawn with clarity or meaning between forced marriages and arranged marriages - if the determinant is full and free consent to wed - is demonstrably misleading. Yet despite contrary protestations, nullity cases in England and Wales and Australia (and originally Fiji) where duress is in issue ultimately rely on variations on force - consistent with Wilson LJ's view in Quila. The notion that culture removes arranged marriages from categorisation as forced also impacts with fraud.

\section{NULLITY UNDER STATUTE}

The Family Law Act 1975 (Cth) recognises nullity "based on the ground that the marriage is void”: s 51 The Marriage Act 1961 (Cth) says

24 Convention for the Protection of Human Rights and Freedoms, $<$ http://www.echr.coe.int/Documents/Convention_ENG.pdf $>$ accessed 21 April 2014.

${ }^{25}$ Quila (ibid (n 4)) [9]. 
a marriage is void where consent of either party is not a real consent because:

(i) it was obtained by duress or fraud;

(ii) that party is mistaken as to the identity of the other party or as to the nature of the ceremony performed; or

(iii)that party is mentally incapable of understanding the nature and effect of the marriage ceremony; .... s 23B(1)(d)

Although Australia and Fiji refer to void and not voidable marriages, while the Matrimonial Causes Act 1973 (EW) refers to both, these provisions originate in common law. Matters akin to those covered by $\mathrm{s}$ 23B (Marriage Act (Cth)) and s 32 (Family Law Act (Fiji)) come under s 12 of the Matrimonial Causes Act (EW) as voidable:

- either party has not consented to the marriage, by reference to duress, mistake, unsoundness of mind or otherwise, or capability for valid consent not lacking at time of marriage, but either party suffering from a mental disorder (per the Mental Health Act 1959 (EWS)) of such kind or to such extent as to be unfitted for marriage;

- the respondent suffers from communicable venereal disease at the time of the marriage, or is pregnant by a person other than the applicant.

Focusing on duress and fraud, noting the (purported) forced and arranged marriages distinction, how are these provisions applied and what is the common law background continuing to influence outcomes?

\section{CONSENT, COERCION, FORCE AND DURESS}

Wilson LJ's apparent contention (in Quila) that lack of consent must be proven with additional use of force obfuscates full and free consent and lack of it.

Consent is:

- "permission for something to happen or agreement to do something"; ${ }^{26}$ or

- "to give assent or approval"; ${ }^{27}$ or

${ }^{26}$ Shorter Oxford English Dictionary (5 ${ }^{\text {th }}$ edn, OUP 2002).

${ }^{27}$ Merriam Webster Dictionary (11 ${ }^{\text {th }}$ edn, Random House 2005). 
- a "concurrence of wills" where:

"Express consent is that directly given, either lira voce or in writing. Implied consent is manifested by signs, actions, or facts. Or by inaction or silence, which raise a presumption that consent has been given ... It is an act of reason, accompanied with deliberation, the mind weighing as in a balance the good or evil on each side.” 28

"Force" is defined as "compulsion, constraint or obligation to do something"; "driving or propelling against resistance"; 29 "to bring about or effect by force" or "bring about of necessity or as a necessary result"; "to put or impose (something or someone) forcibly on or upon a person"; 30 "to compel by force; overcome the resistance of"; "exertion or the use of exertion against a person or thing that resists; coercion." 31 "Coercion" is "to make (someone) do something by using force or threats"; "to get (something) by using force or threats"; 32 "to restrain or dominate by force"; "to compel to an act or choice"; 33 "to achieve by force or threat". 34 "Duress" is "compulsion by threat or force, coercion, constraint"; "Law: such constraint or coercion as will render void a contract or other legal act entered or performed under its influence", ${ }^{35}$ "forcible restraint, especially imprisonment". ${ }^{36}$ Synonyms include intimidation, pressure, bullying, browbeating."Full and free” imports the notion that a party suffers no irresistible impediment or pressure on their will so as to overbear it. Contemporary nullity cases assert that overt force or threats of a physical nature are unnecessary. Yet Scott $v$ Sebright ${ }^{37}$ continues to be cited as leading authority. Butt $\mathrm{J}$ in this case asserts that for fraud and duress consent to marriage should be "tested and determined in precisely the same manner as ... any other contract”, Butt J continued:

"True it is that in contracts of marriage there is an interest involved above and beyond that of the immediate parties. Public policy requires that marriage should not be lightly set aside, and

\footnotetext{
${ }^{28}$ Black's Law Dictionary (10 ${ }^{\text {th }}$ edn, Thomson West 2014).

${ }^{29}$ Random House Dictionary (Random House 2011).

${ }^{30}$ World English Dictionary (OUP 2012).

${ }^{31}$ Collins English Dictionary (11 $1^{\text {th }}$ edn, HarperCollins, Glasgow, 2011).

${ }^{32}$ Random House Dictionary (n 29).

${ }^{33}$ World English Dictionary (n 30).

${ }^{34}$ Collins English Dictionary (n 31).

${ }^{35}$ Random House Dictionary (n 29).

${ }^{36}$ Collins English Dictionary (n 31).

37 (1886) 12 PD 21.
} 
there is in some cases the strongest temptation to the parties more immediately interested to act in collusion in obtaining dissolution of the marriage tie. These reasons necessitate great care and circumspection on the part of the tribunal, but they in no wise alter the principle or the grounds on which this, like any other contract, may be avoided." 38

Butt J went on to disagree that to avoid a contract entered into through fear "the fear must be such as would impel a person of ordinary courage and resolution to yield to it", for:

\begin{abstract}
"Whenever from natural weakness of intellect or from fear whether reasonably entertained or not - either party is actually in a state of mental incompetence to resist pressure improperly brought to bear, there is no more consent than in the case of a person of stronger intellect and more robust courage yielding to a more serious danger. The difficulty consists not in any uncertainty of the law on the subject, but in its application to the facts of each individual case.”39
\end{abstract}

Butt J's contention as to mental incompetency; his implication that duress or coercion must involve danger, even serious danger and fear; and his focus on prioritising "maintaining" marriage are troubling. Although appearing to be a concession to recognising different levels of capacity to resist pressure to consent, "mental incompetency" effectively does the opposite. At the very least it implies that the person (who is not of "more robust courage and stronger intellect") must, to establish absence of consent, be lacking in "ordinary" mental capacity ("weakness of intellect”). Yet a person of ordinary mental capacity (and one robust, of stronger will or even "courage") may well be overborne by religious or cultural expectations and filial duty, whether there is danger, "serious danger" or what might be accepted as fear in reaction to danger. In any event, incompetence of mind such as to impede a person's capacity to understand the nature or effect of marriage or that $s /$ he is participating in a marriage ceremony is now covered by a separate head: s 23B (d) (ii) and (iii) of the Matrimonial Causes Act (Cth), s 32(2) (d) (ii) and (iii) of the Family Law Act (Fiji), and s 12 of the Family Law Act (EW). Why import a mental incompetency requirement into duress or force? Even if done to expand the scope of force or duress it simply adds confusion. As for Butt J's reference to policy, surely an equally compelling "interest ... above

${ }^{38}$ Ibid [23] This is so for Canada, too: $R H v$ RT 2011 BCSC 67.

${ }^{39}$ Ibid [23-24]. Similarly for Canada: $R H \vee R T$ (ibid). 
and beyond that of the immediate parties" is to make sure that no marriages are entered into without full and free consent. The policy requirement not to maintain such marriages must be just as important (or more so) a public interest as maintaining marriages entered into by full and free consent. This is the impetus behind concerns as to forced marriage - and arguably equally applicable to arranged marriages. ${ }^{40}$

More recent cases purportedly abjure Scott $v$ Sebright's notion that duress must involve danger and fear. Hirani $v$ Hirani ${ }^{41}$ is frequently cited. There, annulment was refused at first instance on the basis that duress asserted as applied by Ms Hirani's parents was not duress as required by law. Nineteen at the time of the marriage, Ms Hirani was living in England with her parents, British Indian Hindus who objected to her association with Mr Hussain, a Muslim of Indian background. They arranged for her marriage to Mr Hirani whom she and her parents first met at the registry office. The threats directed to Ms Hirani and upon which she relied were articulated as:

"You want to marry somebody who is strictly against our religion? He is a Muslim, you are a Hindu; you had better marry somebody we want you to, otherwise pack up your belongings and go. If you do not want to marry Mr Hirani and you want to marry Mr Husain, go." 42

The Court accepted that leaving the family home meant Ms Hirani had "no place to go and no means of supporting herself at that age and in those circumstances", and "in spite of her opposition, ... was forced to go through with the civil ceremony" ${ }^{43}$ Consistent with Hindu tradition, she returned to her parents' home, going to live with Mr Hirani after the religious/traditional ceremony some six weeks later. Ms Hirani's evidence was that she "was crying all the way through" the ceremony and "was utterly miserable". ${ }^{44}$ She lived with Mr Hirani for six weeks, not engaging in sexual intercourse with him. Upon leaving, she went to Mr Hussain. Granting the appeal and annulment, Ormrod LJ said it was not necessary to find a threat to life, limb or liberty to establish duress, the key question being "whether threats or pressure were such as to overbear" the

\footnotetext{
${ }^{40}$ As to arranged marriages see further below.

${ }^{41}$ [1982] EWCA Civ 1, [1983] 4 FLR 232.

${ }^{42}$ Ibid.

${ }^{43}$ Ibid.

${ }^{44}$ Ibid.
} 
individual's will, destroying the reality of consent. ${ }^{45}$ Whatever form duress takes, "it must involve coercion of the will so as to vitiate consent". ${ }^{46}$ The threats and pressure employed by Ms Hirani's parents "clearly overbore her will", invalidating or vitiating consent. ${ }^{47}$

This contests Szechter $v$ Szechter ${ }^{48}$ where threat to life, limb or liberty was the criterion by which reality of consent should be measured. ${ }^{49}$ Yet shortly before Hirani, Singh $v$ Kaur $^{50}$ reiterated this standard, saying a lack of threats to life, limb or liberty meant the nullity application was rightly refused, relying on Singh $v$ Singh ${ }^{51}$ In the latter, Ms Singh was 17 years when undergoing a civil marriage ceremony, never having met the man previously. Being Sikh, the coercion she related was religion, custom and duty to her parents. This was considered inadequate to vitiate consent. In the former, whilst in India, a 21-year-old who from four years of age had lived in England was told by his parents that refusing to marry the partner they had chosen would bring shame upon the family and he would be disowned - banned from the family home and family business. His contention that emotional coercion vitiated consent was not accepted as life, limb or liberty threatening.

Nonetheless, in $N H v M I,{ }^{52}$ Munby J observed it is "no longer the law, if it ever was", that marriage was voidable for duress "only if ... there was threat of immediate danger to life, limb or liberty ..." 53 Yet $N H \vee M I$ ultimately hung upon facts clearly showing extreme force and threats:

\footnotetext{
${ }^{45}$ Ibid 2-3.

${ }^{46}$ Ibid 3.

${ }^{47}$ Ibid.

${ }^{48}$ [1971] P 286.

${ }^{49}$ Ibid 297-98.

50 [1981] FamLaw 152.

${ }^{51}$ [1971] P 226.

52 [2006] EWHC 1646 (Fam).
}

${ }^{53}$ Ibid [27], citing Szechter ibid (n 48)), Singh $v$ Singh (ibid (n 52)) and Singh $v$ Kaur (ibid (n 51)) as support for the earlier position, and Hirani (ibid (n 41)) as the 'new' position. For a view on the situation in Australia, where the authors assert a 'disjuncture between domestic legal and political responses to forced marriage faced by nationals of Western states with the response of refugee law to forced marriages occurring elsewhere' see Catherine Dauvergne and Jenni Millbank, 'Forced Marriage as a Harm in Domestic and International Law' (2010) 73 (1) MLR

<http://papers.ssrn.com/sol3/papers.cfm?abstratct_id=1563842> accessed 2 May 2014. As the present article confirms, Dauvergne and Millbank attribute greater latitude in nullity applications than exists in practice. See also Frances Simmons and Jennifer Burn, 'Without Consent: Forced Marriage in Australia' (2012) 36 Melbourne University Law Review 970. Similarly for the UK, David Bradley, 'Duress and Arranged Marriages' (1983) 46 MLR 499; A Bradney, 'Duress, 
- Living in England since her birth, NH was taken to Pakistan shortly after her sixteenth birthday, ostensibly a holiday her parents assured her was not for the purpose of marriage;

- Her expectation (based on parental assurances) of returning to England two months later went unfulfilled: $\mathrm{NH}$ was kept in Pakistan by relatives, until at 17 years she underwent a marriage ceremony with her 17-year-old cousin;

- Between arriving in Pakistan and marriage, realising or at least concerned marriage was planned, $\mathrm{NH}$ constantly telephoned her parents, particularly her mother, for clarification, begging to return to England;

- Her mother prevaricated, saying her father would be arriving and NH should remain to be in Pakistan with her father;

- Eventually her mother confirmed marriage as the purpose, her cousin the chosen partner (her mother's brother's son);

- NH's boyfriend sent his parents to ask for her hand in marriage, creating disturbance amongst the relatives and consternation for her parents, who threatened suicide if she refused to marry the cousin;

- Her parents told NH she would not be allowed to return to England unless she participated in the marriage;

- After the marriage, NH lived in the cousin's household without intercourse occurring, and signed documents only when her mother said she would not be allowed to return to England without signing.

At minimum, being held against her will - false imprisonment or kidnapping - comes within the strictures of threat to life, limb or liberty. This is a common pattern. First, court assertions that such extreme coercion is not required. Then, nullity granted on coercion fulfilling the "old" - said to be obsolete - standard. Hirani exhibits this - being "thrown on the street" at 17 years, disowned by family, without financial resources.

Family Law and the Coherent Legal System' (1994) 57 (6) MLR 963; Anne Phillips and Moira Dustin, 'UK initiatives on forced marriage: regulation, dialogue and exit' (2004) 52 (3) Political Studies 531 and Canada, Bruce Ziff, 'Recent Developments in Marriage and Divorce' (1986) 18 Ottawa Law Review 21. 


\section{AUSTRALIAN CASES}

Australian cases reiterate that life, limb and liberty need not be threatened or at stake. Yet again nullity is granted where clear threats or physical force, kidnapping or false imprisonment and the like exist. Cases where these are not present, yet nullity is granted, are elusive. ${ }^{54}$ In the Marriage of $S^{55}$ is cited as leading authority. Ms S arrived in Australia with her family from Egypt. At 16, she married in a Coptic Orthodox Church. Her evidence was that the marriage took place against her will, under parental pressure:

“... right up to the time of the ceremony I still did not want to go through with it. My parents ... insisted I go through with it and I could not stand up against them." ${ }^{56}$

Watson J held she was "caught in a psychological prison of family loyalty, parental concern, sibling responsibility, religious commitment and a culture [demanding] filial obedience" and, if having "no consenting will", it was "because these matters were operative - not threats, violence, imprisonment or psychological constraint”. ${ }^{57}$

Referring to Scott v Sebright and Cooper (falsely called Crane) $v$ Crane, ${ }^{58}$ Watson $\mathrm{J}$ said the emphasis in some judgments "on fear and terror ... seems unnecessarily limiting” because:

"A sense of mental oppression can be generated by causes other than fear or terror. If ... circumstances ... taken together lead to the conclusion that because of oppression a particular person has not exercised a voluntary consent to a marriage, that consent is vitiated by duress and is not a real consent. This is so howsoever the oppression arises and irrespective of the motivation or propriety of any person solely or partially responsible for the oppression." 59

\footnotetext{
54 See further 'Culture, Force and Fraud', re Nagri \& Chapal [2012] FamCA 464 (1 June 2012).

55 (1980) 42 FLR 94.

56 Ibid 98-99.

57 Ibid 103.

58 (1981) P 369.

${ }^{59}$ In the Marriage of S, (ibid (n 55)) 104.
} 
The effect of oppression on the individual's mind, not the form of oppression (whether constraint, threat or otherwise), "should be the operative factor" and:

“... I cannot see how I can read down the natural and ordinary meaning of "duress" as equated to oppression or "coercion" to such a degree that there is to be no annulment where the lack of real consent arises from non-violent but nevertheless controlling parental coercion., ${ }^{60}$

Not insignificantly, Ms S was 16 at the time of the marriage, economically dependent upon and living at home with her parents, paralleling Hirani. Even if Ms S were not orally threatened with being evicted from the family home and disowned, this was at least implicit. Thus in practical terms the Scott $v$ Sebright approach persists. If this were not so, reported grants of nullity on the basis of religious and cultural imposition or pressure and filial duty without additional pressures such as economic dependency would be in evidence.

In referring as it does to oppression as interfering with "voluntary consent" In the Marriage of $S$ endeavours to position duress in a context admitting of imposition comprehending more than narrow notions of force or threat of force. Yet cases citing In the Marriage of $S$ ultimately generally rely upon far greater explication of coercion or duress, often continuing to refer to Scott $v$ Sebright and Cooper $v$ Crane. ${ }^{61}$ Take, for example, Zoumaris \& Paradisio. ${ }^{62}$ The facts properly led to a refusal of nullity. However, despite giving a nod to In the Marriage of $S$, Burr $\mathrm{J}$ said:

"Duress requires the consent of one party to have been obtained by force or threat of force. It is not sufficient for the strong will of one to have imposed on the will of a weak or impressionable character ...”63

This recurs time and again, with duress or coercion applied by reference to physical or threated physical assault or constraint including

\footnotetext{
${ }^{60}$ Ibid.

${ }^{61}$ See further on Cooper v Crane (ibid n 58) under fraud, supra.

62 [2008] FamCA 688 (1 August 2008).

63 Ibid [24].
} 
kidnapping or false imprisonment (often with passport confiscation), similar threats, or threats of parental suicide - as in Hirani. ${ }^{64}$

Kreet \& Sampir ${ }^{65}$ is typical. Ms Kreet was born in Australia. Her parents came to Australia from India, remaining "closely connected to [that] country's culture ... strict in that regard and ... strongly against much of Australian culture." ${ }^{66}$ Ms Kreet could not cut her hair or wear skirts or dresses apart from school uniform. Then:

- Meeting $\mathrm{Mr} U$ through social media, she concealed the relationship from her parents until a year later. Unhappy, her parents said she could not marry $\mathrm{Mr} \mathrm{U}$, demanding she cease that contact and threatening an arranged marriage for her in India if she refused. Mr Kreet kept her from school, confiscated her mobile phone, and stopped her internet access.

- The relationship continued. Ms Kreet's father said he was considering wedding proposals notified to him by her Indian uncle and, once 18, she would go to India with him for an arranged marriage and "appropriate suitor".

- Following November 2008 final examinations, Ms Kreet removed to Melbourne to live with $\mathrm{Mr}$ U. Her parents reported her as "missing”, repeatedly telephoning her to persuade her return. Her statutory declaration ended the police investigation, confirming she was in Melbourne of her own free will. Her parents travelled to Melbourne, advising her that once 18 she could marry Mr U. He and Ms Kreet participated in an "engagement ceremony" in Ms Kreet's parent's presence, which Ms Kreet termed a "proclamation in front of God" ${ }^{\text {"7 }}$ that she would marry Mr U.

- Back in Sydney, Ms Kreet was assailed by her parents' efforts to persuade her to end the relationship with $\mathrm{Mr} \mathrm{U}$. Mr Kreet made

\footnotetext{
${ }^{64}$ Rees J in Tirta \& Lim [2012] FamCA 63 (23 February 2012) sees “difficulty [as arising] in the past ... where, for example, the other party had threatened to commit suicide": 6 . A suicide threat by the other party was not accepted as duress in Kecskemethy (Otherwise Magyar) v Magyar (1961) 2 FLR 437 where he showed the putative marriage partner bloody clothing as 'evidence'. The threat occurred sometime before the marriage; however Ms Kecskemethy said fear for Mr Magyar's life was continuing, motivating her consent.

65 [2011] FAMCA 22.

${ }^{66}$ Ibid [9].

${ }^{67}$ Ibid [15].
} 
direct threats to $\mathrm{Mr} \mathrm{U}$ that he would kidnap and rape Mr U's mother and sisters. In early 2009, he slapped his daughter's face on two occasions and struck her on the back. Ms Kreet returned to Melbourne, advising police that she was living with Mr U freely.

- Ms Kreet's parents flew to Melbourne, persuading her to return to Sydney. Apologising and asking her to forgive them, they offered a "proper wedding" to Mr U in India for her eighteenth birthday. Mr U went to Sydney to discuss wedding plans. Ms Kreet agreed to a traditional wedding with $\mathrm{Mr} \mathrm{U}$ in India.

- In India, her parents confiscated Ms Kreet's passport, denied her telephone rights with $\mathrm{Mr} \mathrm{U}$, and concluded discussions about "suitable husbands" by providing one whereupon Ms Kreet's refusal was met with Mr Kreet's repeated threat to rape and kidnap Mr U.'s mother and sisters.

- Thus arranged, the marriage went ahead.

Again, coercion or duress included physical assault, confinement and threats. Notably, too, the applicant/petitioner's youth is a central feature. This and the risk of economic survival parallels Hirani and In the Marriage of $S$. Hence the question whether more than lip service is paid to filial duty, cultural imposition and religious factors in arranged marriages. What of these factors in fraud and arranged marriage?

\section{FRAUD AND CONSENT - MOSS $v$ MOSS}

Fraud nullity cases return to Moss $v$ Moss (Otherwise Archer), ${ }^{68}$ Scott $v$ Sebright and Cooper (falsely called Crane) v Crane. Post-dating them, Australian, English and Fijian statutory provisions set out explicitly some circumstances these authorities discuss under fraud generally. The insight provided is instructive.

Involving pregnancy concealed at time of marriage, in Moss fraud is considered in two aspects:

- impersonation leading a party to marry another, not realising that that other is not the actual person (physical person) s/he believes is the contracting party; and

68 [1897] P 263. 
- deliberate inducement of a person with a disability - expressed as "feeble minded" - to marry.

Mr Moss married, not at the time (fully) realising his bride was pregnant to another man. Ms Archer, the bride, hid this from Mr Moss. Originally meeting when both were in service, Ms Archer and Mr Moss re-met in 1895, thereafter seeing one another occasionally. In mid-1896 at her father's house, she "pressed” Mr Moss to marry her. He agreed. Later that year, at the wedding, his "suspicions for the first time aroused", $\mathrm{Mr}$ Moss "taxed [her] with being pregnant". ${ }^{69}$ She denied it. A week or so later, confessing to the pregnancy, Ms Archer (now Moss) alleged the putative father had seduced her. Mr Moss left. A month later, the child was born. The Court accepted that at the time of marriage Mr Moss "did not know of his wife's condition", having "no grounds” for inquiring "as to her character" ${ }^{\prime 0}$.

Counsel "for" pregnancy concealment as fraud vitiating consent contended: ${ }^{71}$

- no English court decision addressed a prospective wife's concealment of pregnancy from the intended husband at time of marriage as a nullity ground;

- nonetheless the facts fell "within the principle of law [avoiding] a contract on the ground that consent of [a party was] obtained by fraud";

- a marriage contact's validity is "dependent upon the same considerations" as any other contract's validity, to be "tested in the same way";

- both parties' consent is mandatory, being consent with "knowledge on their part of all material facts";

- "a material fact was suppressed" by the intending wife;

- her conduct was a fraud on the husband, any child born in wedlock being presumed his, requiring him to "support another man's child";

- pregnancy at time of marriage "rendered [Ms Archer] incapable ... of bearing a child to her husband" at that time and, through concealment, was a fraud on "essentials of the marriage relation";

- US authority establishes by Reynolds $v$ Reynolds ${ }^{72}$ "clear law that concealed pregnancy is a ground of nullity", and by Donovan $v$

\footnotetext{
69 Ibid 265.

${ }^{70}$ Ibid 266.

${ }^{71}$ Ibid 266-267.
} 
Donovan $^{73}$ that a wife's "express representation of chastity" before marriage is unnecessary.

Counsel contesting fraud said: ${ }^{74}$

- all essentials of a valid marriage contract were present intelligent consent, free agency, complete age and physical capacity, and statutory compliance;

- fraud is a ground for nullity only where "of such a nature as to be inconsistent with the idea of ... a real and intelligent consent" by a party;

- although based on the parties' contract, marriage "is not merely a contract in the ordinary legal sense of the term", as creating a status: Niboyet $v$ Niboyet $^{75}$ per Brett, LJ; Sottomayer $v$ De Barros, ${ }^{76}$ per Lord Hannen;

- the wife being "under the circumstances incapable of bearing children to her husband" is countered, this being "at most a temporary disability";

- the US decisions conflict with English law and should not be followed.

Jeune P refused nullity: lacking precedent it "would be impossible ... , at the present day" to endorse a principle "of such importance and so farreaching." 77

On identity fraud, he cited Swift $v$ Kelly ${ }^{78}$ : absent explicit statutory provisions "requiring certain things to be done in a specific manner", a marriage contracted on false representations, where "but for such contrivances, consent never would have been obtained" could not be held void:

"Unless the party imposed upon has been deceived as to the person, ... thus [giving] no consent at all, there is no degree of

\footnotetext{
7285 Mass (3 Allen) 6-05 (1892).

7391 Mass (9 Allen) 140 (1864).

${ }^{74}$ Moss (ibid (n 68)) 265.

75 (1815) 3 M\&S 537.

76 (1879) 5 PD 94, 101.

${ }^{77}$ Moss (ibid (n 68)) 267.

${ }^{78}$ (1835) 3 Knapp 257.
} 
deception which can be available to set aside a contract of marriage knowingly made."79

Marriage contracts were distinguished from ordinary commercial contracts, marriage being "a civil contract and a religious vow" parties are not entitled to dissolve of their own volition. ${ }^{80}$ This tends to Munby J's public interest or public policy argument in NS $v$ MI.

Moss limits (in ways applicable neither to the Australian, Fiji nor current UK position) the grounds upon which marriage can be annulled. Setting this out in detail is essential to understanding fraud in present law, consistent with relevant statutory provisions. In Moss, Jeune P pinpointed the need for:

- both parties' voluntary consent;

- compliance with legal requirements of publication and solemnisation, so far as law deems essential;

- no incapacity in parties either by age, physical capacity or relationship by blood or marriage.

He said failure in those respects, but (he believed) in no others served to render a marriage void or voidable:

"It has been repeatedly stated that a marriage may be declared null on the ground of fraud or duress. But, on examination, it will be found that it is only a way of amplifying the proposition long ago laid down ... that the voluntary consent of the parties is required." 81

As with any other contract, duress in marriage contracts is, Jeune $\mathrm{P}$ said, "an absence of a consenting will", and with fraud, this "does not include such fraud as induces a consent, but is limited to [that procuring] the appearance without the reality of consent": ${ }^{82}$

- the most simple instance is personation, or as per Lord Ellenborough in Rex v Burton-on-Trent ${ }^{83}$, adopting another name for concealment vis-a-vis the putative marriage partner; or

\footnotetext{
${ }^{79}$ Ibid 293.

${ }^{80}$ Moss (ibid (n 68)) 267.

${ }^{81}$ Moss (ibid (n 68)) 268, citing Fulwood's case (1638) Cro Car 482, 488, 493.

82 Ibid (n 68).

83 (1869) 3 M\&S 537.
} 
- taking advantage of a "weak" though not "absolutely insane" mind to induce entry into a contract despite a party's lack of understanding: Portsmouth $v$ Portsmouth ${ }^{84}$, Harrod $v$ Harrod. ${ }^{85}$

In all cases where fraud constitutes a marriage nullity ground indicates procurement of agreement by form without substance. Annulment flows not because fraud is present, but because consent is absent:

"This is illustrated by the imaginary case suggested ... in Reg $v$ Mills ${ }^{86}$ of a mock marriage in a masquerade where the kind of result ... fraud might have produced would be produced by mistake. [There], there would be no fraud, but for want of real consent the marriage would be declared void. But when there is consent no fraud inducing that consent is material." ${ }^{87}$

Referring to Wakefield $v$ Mackay ${ }^{88}$ Jeune P noted similar, more recent cases where error as to family or fortune procured by "disingenuous representation" cannot contradict marriage validity, for "no disparity of fortune or mistake [of] qualities of the person" can impeach "the vinculum of marriage": 89

"The strongest case [established] of the most deliberate plot, leading to a marriage the most unseemly in all disproportions of rank, of fortune, of habits of life, and even of age itself, would not [release] from claims which though forged by others, he had riveted on himself. If he is capable of consent and has consented, the law does not ask how the consent has been induced." 90

Scott $v$ Sebright is often cited for a broader nullity concept. This Moss explains as a misreading: it was "a case of deception and force acting on a weakened mind", simply establishing that for marriage, as for other contracts, fraud and duress may "render an apparent consent in truth no

\footnotetext{
841 Hagg Ecc 355.

85 (1854) 1 K\&J 4.

${ }^{86}$ (1844) $10 \mathrm{Cl} \& \mathrm{~F} 534,785$.

${ }^{87}$ Moss (n 68) 268-69.

881 Phillim 134, n 137.

${ }^{89}$ Moss (ibid (n 68)) 269 citing Ewing $v$ Whatley 2 Hagg Cons 175, 183.

${ }^{90}$ Moss (ibid (n 68)) 269-270 citing Sullivan v Sullivan (1818) 2 Hagg Cons 283, 284.
} 
consent at all”. ${ }^{91}$ Moss thus seeks to establish within its own parameters what was said in Scott $v$ Sebright, namely that courts refuse to "recognise as binding contacts [where] consent of either party [is] obtained by fraud or duress", and the validity of a contract of marriage must be tested and determined in precisely the same manner as that of any other contract. ${ }^{92}$

\section{WHAT THEN OF THE STATUTORY PROVISIONS? FRAUD AND CONSENT BY STATUTE}

Moss says marriage can be annulled only where there is no consent: however or by whatever means induced, consent makes a marriage valid. Statute law puts it differently. The Matrimonial Causes Act (EW) diverges from the Family Law Act (Fiji) and Marriage Act (Cth), which explicitly include "fraud". However, the EW Act refers to "valid consent", listing all matters for a void or voidable determination. The Australian and Fiji Acts refer to "consent" that is "not a real consent", listing specifics: s 32(2) (d), s 23B (1)(d)

The distinction matters.

First, to Moss where nullity must be based on:

- no incapacity in the parties to marry - including age, physical capability or relationship by blood or marriage;

- no absence of a consenting will;

- fraud limited to that procuring an appearance of consent, without reality, including:

o personation;

0 assumed name for concealment from putative partner;

0 advantage taken of a mind "not absolutely insane, but weak", to induce entry into a contract the party "did not understand";

o procuring form without substance of agreement not by fraud, but by absence of consent (citing personation, assuming a name, taking advantage of a weak mind);

o mock marriage or masquerade. ${ }^{93}$

Frauds not qualifying for nullity include:

- disparity of fortune or mistake as to the person's qualities;

\footnotetext{
${ }^{91}$ Moss (ibid (n 68)) 270.

92 Moss (ibid (n 68)) 270-71.

93 Moss (ibid (n 68)) 268-69.
} 
- a "most deliberate plot, leading to marriage most unseemly in disproportion of rank, fortune, habits of life, even age". ${ }^{94}$

Then to statute law. In Australia and Fiji, those matters specified by Moss are covered explicitly:

- identity mistake;

- nature of the ceremony mistake;

- mental incapacity as to understanding nature and effect of the ceremony: s 32(2)(d)(ii)(iii) Fiji, s 23B(1)(c)(ii)(iii) Australia

As fraud remains a separate head (s 32(2)(d)(i) Family Law Act (Fiji), s 23B(1)(d)(i) Marriage Act (Cth), it must have a meaning beyond these.

The Family Law Act (EW) references unsoundness of mind, mistake, venereal disease, pregnancy and gender identity. Are the listed matters intended to be exhaustive? Fraud could come under "otherwise":

That either party to the marriage did not validly consent to it, whether in consequence of duress, mistake, unsoundness of mind or otherwise: s 129(c)

The question is what are "fraud" (in Australia and Fiji) and "otherwise" (EW) designed to cover?

In Australia, In the Marriage of Nemer Osman Husband and Oula Mourrali Wife Suit ${ }^{95}$ refers to Moss and Deniz and Deniz. ${ }^{96}$ In Deniz, a Turkish national accepted by the Court as lacking any intention whatsoever of cohabiting, persuaded an Australian schoolgirl of Lebanese descent to marry him, aiming solely to secure permanent residency. Holding fraud not to be limited to identity or nature of the ceremony, the Court granted the annulment. A distinction was drawn between consent gained through a fraudulent representation by the respondent as to living with an applicant as husband and wife as opposed to a fraudulent representation that the respondent had riches, good-looks, virtue, health or any such "inducing equality".

Osman $v$ Mourrali ${ }^{97}$ and Otway and Otway ${ }^{98}$ rejected Deniz, conforming to the traditional view. Yet that cannot be right: with

\footnotetext{
${ }^{94}$ Moss (ibid (n 68)) 269-70.

95 [1989] FamCA 78 (17 November 1989), (1990) FLC $\mid 92-111$.

96 (1977) FLC $\$ 90-252$.

97 [1989] FamCA 78 (17 November 1989), (1990) FLC $\mid 92-111$.
} 
"identity" and "nature of the ceremony" explicitly covered under section 23 , that would render otiose the explicit reference to fraud.

Nevertheless, Fiji initially adopted the same approach. In MPL $v$ $J S G^{99}$ Pulea CJ refused a nullity application where an arranged marriage was initiated by JSG's father. Asking whether JSC had married previously and "[is] there anything I won't be happy with?” MPL's father was told JSG had never married and "my son is very good and that is why I came and asked for your daughter's hand". 100

Within two weeks of completed marriage negotiations the parties married. The husband then returned to Aotearoa/New Zealand, MPL and her family in Fiji hearing nothing more from him. By telephone, the fathers planned the traditional religious wedding. Then, according to MPL's father:

“[JSG's father] called me ... and I was preparing everything as it was coming near to ... the ceremonial wedding and he said: 'I have some bad news ...' He said: 'Why can't you shift the marriage.' I asked ... why and he told me his son was involved in a drug case and 'he takes drugs a lot. He is not staying with me anymore... he does not listen to [me]." ${ }^{101}$

The drug problem arose at no time during marriage negotiations or on the wedding day, with repeated assurance of JSG's being "a good boy and hard working. He will look after your daughter very well ...”102

Arguing fraud under s 32(2)(d)(i), MPL's father said consent would never have been given, had the drug problem been known. Relying on Moss, In the Marriage of Hosking, RG and Hosking, $\mathrm{JH}^{103}$ and Osman and Mourrali, Pulea J refused nullity, observing that in each case the basis for declaring marriage "null" for fraud does not include fraud inducing consent. Citing Hosking and Moss she said fraudulent misrepresentations of the quality of a person or future intentions "have never been regarded as sufficient to annul a marriage." 104

Observing that, "consent and fraud" principles being "grounded in a long list of authorities" and having "developed over the years.” Pulea J said there should be no extension to "deliberate withholding of

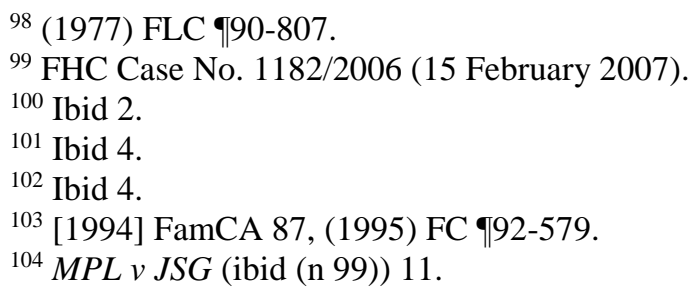


information [here, the] drug problem and misrepresentation." 105 The alternative "would appear to be so wide as to cover any situation [involving] lack of information of the conduct, character and circumstances" of a putative partner. ${ }^{106}$ Echoing Jeune P in Moss she said that introducing "a new principle not resident on any sound basis" would prompt development "in several directions, [giving] rise to many doubts and much confusion.” 107

Albeit sympathising with MPL, Pulea J said nullity fraud did not include misrepresentation and concealed misconduct:

"In Swift v Kelly (1835) Knapp 257 the Court held: ' $\ldots$ no marriage shall be held void merely upon proof that it had been contacted upon false representations and that for such contrivances, consent would never have been obtained.' In Hosking $v$ Hosking (1995), p. 81,750, the Court concluded that the term 'fraud' as it appears in s. 23B (1) (d) of the Marriage Act [1961] (Cth) has a fairly limited scope. Its concern is with fraud as to the identity of the other party or as to the nature of the ceremony, and not to the motives of a party in entering into the marriage." 108

Yet motive is not the issue. Section 32(2) (d) (i) is directed to what, when "consenting," is the mind of the person alleging fraud, and the nature of that fraud. All manner of matters may be the subject of pretence or misunderstanding, misrepresentation or mistake and lack of meeting of minds when parties court and marry. All cannot go to fraud within the meaning of s 32(2) (d) (i) and its Australian equivalent. However, some may.

Cases are inconsistent. Courts in England and Wales and Australia (as in the US - see Moss) vary in approach. Sullivan $v$ Sullivan (Falsely called Oldacre) $)^{109}$ lists "fraud" not vitiating marital consent: (false) representations of money - or exaggerating the prospective partner's wealth, (mis)representing class or status, concealing a drug or drink habit. These may distress the party discovering the truth after marriage; however none goes directly to appurtenances of marriage. Similarly, assurances that an intended marriage partner is "a good boy" (or "man”).

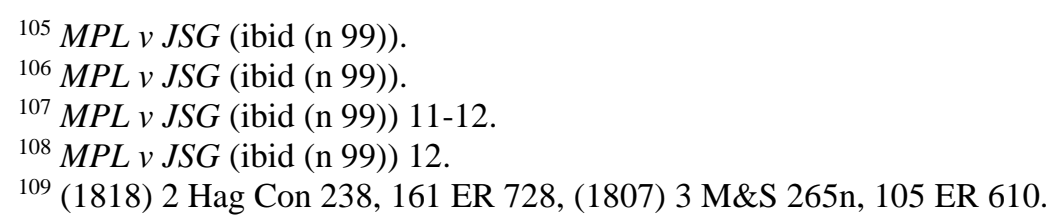


Australia swings between a narrow and more liberal view, some obvious in outcome, some less so. In the Marriage of Otway EJ and Otway, $G^{110}$ is clear-cut. Four days after the wedding, Ms Otway acknowledged she had married only because the man she truly wanted to marry had said he wanted a de facto relationship. After two and a half years, Ms Otway followed that man interstate, eventually living with him. Applying for nullity, Mr Otway argued she had wanted Australian residency to remain Australia and resume her relationship with the other man.

Fraud was ruled out. Each had consented freely, despite Ms Otway's ulterior design unknown to Mr Otway at the wedding. There was no mistaken identity or mistake as to the ceremony or meaning of marriage. Most significantly, having lived as husband and wife, presenting as married and undertaking "couple" activities for $2 \frac{1}{2} 2$ years, it was "drawing a long bow to contend the marriage could be annulled by fraud". ${ }^{111} \mathrm{Mr}$ Otway's route was dissolution.

In Osman and Mourrali, ${ }^{112}$ Mr Osman said, after the ceremony: "I don't want to marry you, the whole purpose of the marriage contract was to obtain residency." "113 One month later, he emphasised to Ms Mourrali's mother that he did not wish to marry Ms Mourrali. Then by telephone he was alleged to have said to Ms Mourrali's mother that he was "no longer interested in marrying her daughter because he had 'legal residence'”. ${ }^{114}$ Mr Osman admitted that conversation, saying he had said he no longer wished to marry Ms Mourrali however he was angry when Ms Mourrali's mother abused him. He claimed the marriage ended because Ms Mourrali assumed he was far wealthier and, discovering her mistake, she "lost interest in the marriage and would not proceed."115

Nygh $J$ reviewed the history and principles of nullity fraud. Canvassing fellow judges, he found immigration fraud applications to be "relatively common", some annulments being granted, others refused when judges followed the "traditional view". Nygh J acknowledged having once granted an undefended application, saying he stressed at the time that light of there having been no argument, this should not be seen as a precedent for:

\footnotetext{
110 (1987) FLC $991-8071$.

111 Ibid.

112 [1989] FamCA 78 (17 November 1989), (1990) FLC $\mid 92-111$.

113 Ibid 77,741.

114 Ibid. The references to 'marry' here are discussed further under 'Duress and Fraud in Forced and “Arranged” Marriage', supra.

115 Ibid 77,741.
} 
“...[I]f a person wishes to go through a ceremony of marriage with [one] whose identity he or she is aware of, then it matters not that that consent is induced by promises of eternal happiness, luxurious living or even the promise to live together for ever after. For, if ... a marriage could be annulled on the ground that a party was defrauded as to the intention to cohabit, where should the court draw the line? Love and affection are also regarded as essential to a marriage at least in the twentieth century: would lack of love base an application for annulment? Again, the production of offspring is a traditional concern of marriage, would a deception as to the intention to bear them or procreate them found an application? Where does one draw the line between attributes such as wealth, virtue, beauty or potency on the one hand and the fundamentals of marriage such as cohabitation, mutual love and support and the procreation of children of the parties?”116

Noting the English approach, inherited by Australia, where marriage would be valid despite neither party's intending to cohabit, he located in inheritance, property and "dynastic relationships" this "peculiarity" of English law not existing elsewhere in the world:

"[A] distinguished historical line of Englishmen from the monarch downwards would have been loath to have their marriages annulled if an intention to cohabit had been of the essence! If cohabitation is not of the essence where neither party desires it, how can it then become of the essence if only one party seeks it?"117

Nygh J relied also on changing social mores. He said changes to divorce "strengthened" the decision to refuse nullity, for annulment had "some attractions" when divorce was "difficult" and viewed as "socially shameful”. Now, with dissolution following one year's separation without any investigation "nor guilt" produces no stigma. Being so easily established, had she sought divorce Ms Osman "would have been relieved far more expeditiously and cheaply from her bonds some time ago."118

Yet just as Pulea J's reference to "motive" was misplaced, so too with Nygh J: the issue is not changing social mores or shame removed from divorce. The question is whether or not there is fraud interfering with the

\footnotetext{
${ }^{116}$ Ibid77,742-77,743.

117 Ibid 77,743.

118 Ibid 77,743-744.
} 
reality of consent. This rests upon the particular facts of the particular case, and all the circumstances.

\section{FRAUD IN FORCED AND ‘ARRANGED’ MARRIAGES}

In Australia, dispute revolves around Deniz, which has created a line of authority generally departing from it. Statute law, Deniz held, excluded ecclesiastical principles limiting fraud to identity or the nature of the ceremony. Osman and Mourrali criticised this. Yet the critique is difficult to fathom in light of the legislation. The Court in Deniz said fraud in the Matrimonial Causes Act and its successors, the Family Law Act and Marriage Act, must mean something more than duress. Otherwise it constitutes "mere surplusage" lacking effective meaning. ${ }^{119}$ Osman and Mourrali responded with a resounding "no". ${ }^{120}$ In the Marriage of Otway endeavoured to address the problem by asserting that the Marriage Act provisions did "little more" than put into "statutory form" the law as "then understood", without liberalising or expanding the meaning of fraud. ${ }^{121}$ The Court contended that retaining fraud whilst explicitly referring to mistake as to identity and the nature or effect of the ceremony was simply a clarification of the reality that an "innocent" as well as a "fraudulent" mistake could result in the "relevant" lack of consent to a marriage. Yet why does the legislation not say so? Both types of mistake are left open as to "innocence" or "deceit", meaning that under the Marriage Act (Cth) s 23B(ii) and (iii) a court could include either innocent or duplicitous concealment on the part of a party. If the intention is to cover both, again there is no need for retaining fraud in s 23B(i).

Legislative interpretation matters.

As well as ignoring the existence of fraud as a head separate from questions of identity and nature or effect of the ceremony, or accepting the attempted distinction made in In the Marriage of Otway, Osman and Mourrali and its followers ignore "or" in s 23B(1)(d)(i) - "duress or fraud" - collapsing duress and fraud or making fraud hang upon some element or elements of duress. The contention is that somehow fraud and duress should be considered together, or are part and parcel of one way (rather than two ways) annulment may be recognised, or consent seen as inoperative or invalid. Yet "or" has legislative interpretation on its side as

119 (1977) FLC $\$ 90-252$.

120 [1989] FamCA 78 (17 November 1989), (1990) FLC $992-111$ at 76, 354.

121 (1818) 2 Hag Con 238, 161 ER 728, (1807) 3 M\&S 265n, 105 ER 610.What the Court meant by 'little more' rather than 'only' remains unexplained. 
creating or indicating alternatives. It also confirms a parliamentary intention to introduce a disjunction: fraud is not limited by duress. Fraud and duress are independent or separate heads by reference to which annulment can be determined and upon which it can be founded. Ignoring s. 23B(1)(i) fraud completely by saying it is limited to s 23B(d)(ii) or (iii) situations is equally wrong.

In Deniz the Court sought to adumbrate possible instances of fraud vitiating consent, applying a secular and contemporary perspective. Hence the approach was similar to that in Sullivan although pointing to the positive - what is fraud, rather than to the negative - what is not fraud.

The Court acknowledged a lack of reported cases, concluding an apparent reluctance to set down principles or guidelines may arise from perceived difficulty in providing "proper safeguards":

"For instance, there would be general consternation if an application was granted on the basis of fraud by reason of one party deceiving the other as to being possessed of natural teeth. The case of the person who marries to gain money, rank or title as distinct from the more usually professed reasons would also cause concern. Clearly the fraud relied on must be one which goes to the root of the marriage contract." 122

Quite rightly, it cannot be up to individual participants to decide what goes "to the root of the marriage contact." This must be determined by courts referable to legislation and parliamentary debates. Deniz applied to the specific facts and recognised the need to interpret "fraud" consistent with safeguards against fanciful or inappropriate claims. ${ }^{123}$ Nygh J's examples in Osman and Mourrali - along with those of Sullivan and the Deniz natural teeth example - of what is not fraud can be endorsed without accepting as impossible devising a pattern or principle founding what can constitute fraud. This does not mean individual idiosyncrasies are indulged. It does mean general acceptance of appurtenances of marriage are recognised.

Impotence appears explicitly in the UK legislation: s 12(a) - applying to both male and female incapacity - although absent a requirement for concealment at the time of marriage. Hence, the UK could be seen as moving away from the fraud proposition altogether - although what

122 [1989] FamCA 78 (17 November 1989), (1990) FLC $992-111$ at 76,354-355 (Emphasis added).

${ }^{123}$ Ibid. 
"otherwise" means in "duress, mistake, unsoundness of mind or otherwise" continues to require explanation.

In $A D$ and $V V P^{124}$ and $K N$ and $E G^{125}$ the Fiji Family Court canvassed fraud in nullity applications where the husband was impotent at time of marriage, not disclosing it, and the wife would not have married him had she known. In both instances, nullity was granted. ${ }^{126}$ As there recognised, marriage is not "all about" sexual relations or childbearing. Equally certain, generally these are part of marriage. People can and do marry without childbearing intentions even when of childbearing age. People can and do marry without intending sexual relations. ${ }^{127}$ Yet this cannot render childbearing and sexual connection irrelevant to marriage or not a part of the generally accepted marriage relation. Hence, if a person marries knowing of his impotence or infertility and concealing it, this should come within fraud as a basis for nullity. Similarly with vaginismus or infertility on a putative wife's part.

Returning then to forced and arranged marriages, just as the meaning of "duress" in both can be questioned, is there a role for fraud? In Quila Wilson LJ saw culture as sanctifying arranged marriages and somehow making consent to marriage real. Should culture be recognised in precisely the opposite way, however - as denying capacity to give free and full consent?

\section{DURESS AND FRAUD IN FORCED AND 'ARRANGED' MARRIAGE}

Nygh J dealt with Osman and Mourrali as immigration fraud. However, a knowledge of Muslim and Hindu practice is essential for understanding the evidence and analysing the case as (possible) fraud under the Family Law Act (Fiji) and Marriage Act (Cth).

What the husband said after the (civil) ceremony was:

\footnotetext{
${ }^{124}$ HCFC 0072/2007, 8 February 2008 (Scutt CJ).

125 HCFC 0029/2008, 12 May 2008 (Scutt CJ).

126 The current writer was Chief Judge of the Family Court Division of the High Court of Fiji with sole jurisdiction in relation to nullity applications.

127 George Bernard Shaw and his wife Charlotte Payne-Townshend married with agreement on these terms: Michael Holroyd, Bernard Shaw: A Biography (Vintage/Random House, London, 1998).
} 
"I don't want to marry you, the whole purpose of the marriage contact was to obtain residency. I am no longer interested in marrying your daughter because I have legal residence.” 128

In Fiji, Hindu and Muslim practice has the civil marriage occurring first - parties often describing this as "engagement". Then a religious or traditional ceremony - Muslim or Hindu - joins parties, and within their culture they are accepted as married. Only after the second ceremony do parties consummate marriage and live as husband and wife. This is, generally, traditional Hindu and Muslim practice in Australia and the UK as the cases show.

The evidence in Osman and Mourrali confirms this pattern: the parties went through the (civil) marriage ceremony, then (according to the evidence, although Mr Osman disputed this) Mr Osman refused to go through the religious or traditional ceremony: "I don't want to marry you ...". "I am no longer interested in marrying ..." arguably referring to the traditional or religious ceremony, a denial of intention to go through that second step, essential to make marriage "real" for Ms Mourrali. $\mathrm{Mr}$ Osman did not need this, as civil marriage gained him the immigration status he sought. Yet the understanding of Ms Mourrali and her mother was that the religious or traditional ceremony would follow. This was the basis upon which consent to the civil ceremony was given.

Thus analysed (that is, cognisant of the cultural background) the immigration issue was motive, hence properly not the basis for fraud. The basis for fraud was the husband's deception as to his intention to marry Ms Osman according to religious or traditional practice. She married him - gave her consent to the civil ceremony - solely on the basis that she and he would then be joined through the religious or traditional ceremony.

Until that time, they would not - and indeed did not - live as husband and wife for, according to religious or traditional practice, they were not husband and wife. This is not to ignore the key factor of legal marriage as the only marriage recognised in law, whether in Australia, Fiji or the UK. Religious marriage would not make the parties married according to Australian, Fijian or England and Waleslaw. But the parties would not have been married in accordance with England and Wales, Australian or Fiji law (that is, civilly) - except for the representation, relied upon by the

128 [1989] FamCA 78 (17 November 1989), (1990) FLC 992-111.at 77,741.The references to 'marry' need to be understood as referring to the religious ceremony that ordinarily follows, or is expected to follow, the civil (legal) ceremony in traditional Muslim and Hindu culture. 
wife (and her mother) that the religious or traditional ceremony would go ahead.

This is a clear fraud within the context of family law - if fraud is to be given meaning in the Marriage Act (Cth) s 23B(1)(d)(i) and s 32(2)(d)(i); it could also come under "otherwise" in s 12(d).

Nygh J's notion that dissolution of marriage being so uncomplicated, its requirements easily complied with, ignores the existence of nullity by fraud in Australian law. Parliament intends parties to have rightful access to nullity. Parties are entitled to be heard on that basis. Spurious and fanciful cases should not be entertained as fraud. However, Osman $v$ Mourrali discloses no basis upon which assertions of fancifulness or spuriousness can be suggested fairly. The substance of the evidence was that Mr Osman clearly misled Ms Mourrali. His motive for misleading her is, as noted, not the issue. Rather, it is what went on in Ms Osman's head at the time of the civil ceremony and her position vis-à-vis marriage. She would not have married - would not have consented to the (civil) marriage, if she had not believed or expected, upon the representations of Mr Mourrali - that she would be married in the eyes of her faith and tradition or culture - through the religious or traditional ceremony. Hence, her consent, though given, was given by reason of fraud. Without the religious or traditional ceremony, Ms Osman was caught in limbo: she would not live with Mr Mourrali (even had he wanted her to) because of her faith, tradition and culture. She could not marry anyone else - as in law, she was married. This is precisely the sort of situation fraud is intended to encompass and nullity is intended to resolve.

Turning then to duress. In Nagri and Chapal ${ }^{129} \mathrm{Mr}$ Nagri claimed duress. He was 25 years at the time of the marriage. The age difference between Mr Nagri and Ms S in In the Marriage of S - she being a minor, he having reached the age of majority some years before marriage - was referred to explicitly by the Court. Nonetheless, nullity was granted, the Court saying:

“... I am satisfied that in this case, because of the relationship between [Mr Nagri] and his uncle, [Mr Nagri] was, at the time of the marriage, the subject of strong feelings of family loyalty. I am satisfied that he accepted his uncle as standing in loco parentis. He was subject to religious and cultural beliefs. He believed that his situation was one where his uncle was entitled to demand his obedience." 130

129 (2012) FamCA 464 (1 June 2012).

130 Ibid [27]. 
Mr Nagri and Ms Chapal (who did not oppose the application albeit her evidence was that she was a fully and freely consenting party) were born in India, a year apart. Mr Nagri arrived in Australia with his mother in 2008, financially supported by his uncle, Mr S, who financially supported and posted a bond for him, giving him employment and financial assistance. In about August 2011, Mr S told Mr Nagri of finding a "girl" whom he (Mr S) thought Mr Nagri should marry. When the parties met in September, Mr Nagri's mother and uncle had decided on the marriage. Mr Nagri attempted to tell his uncle in October that he loved another and did not wish to marry Ms Chapal. Mr S said "it would be impossible at that stage that the marriage not occur" and the marriage "must proceed" as "arrangements" had been made and he (Mr S) had "given his word." "131 That month the Roka (cultural engagement ceremony) ensued, Mr Nagri and Ms Chapal then signing relevant documents at a Registry office, fixing a November date for the legal ceremony. On the November date, the parties performed the civil marriage ceremony. A month later Mr Nagri told Ms Chapal he had married under compulsion and a sense of duty to his family. He apologised unreservedly, asking her forgiveness and saying he had "acted badly". He then refused to participate in the arranged Hindu ceremony, telling his mother in particular that he had hurt Ms Chapal and would not go through with it.

Collier $\mathrm{J}$ referred to In the Marriage of $S$ and Teves III \& Campomayor, ${ }^{132}$ the latter simply as following the former. He noted $\mathrm{Mr}$ Nagri was economically dependent - or at least employment-dependent upon his uncle, however, the judgement principally relies upon family and cultural relationship and duty. Mr S, said Collier J, considered himself to be in a "pater familias" position or something "very similar", believing he "had authority" and "almost absolute" authority over Mr Nagri:

"It was [Mr S - the uncle's] wish that the marriage should go ahead. Indeed, he was quite appalled when [Mr Nagri] suggested .... the marriage might not go further. He told his nephew that all the arrangements had been made. He particularly made it clear that he ... would not go back on his word given to [Ms Chapal's] family, that the marriage would take place ...” 133

This judgment accepts the role duty and obeisance to family play and the power they have in (some) cultural settings. Evidence from both $\mathrm{Mr} \mathrm{S}$

\footnotetext{
131 Ibid.

132 [1995] FLC $\$ 92-578$.

133 [1989] FamCA 78 (17 November 1989), (1990) FLC $992-111$ at [11-12].
} 
and Mr Nagri's mother confirmed pressure, with $\mathrm{Mr} \mathrm{S}$ "prepared to acknowledge that his behaviour in this respect was such that it overbore the will of his nephew at the time the marriage was entered into". ${ }^{134}$

This is somewhat consistent with the import of Watson J's determination in In the Marriage of $S$ in recognising that duress can arise out of oppression in the context of familial relationships and arranged marriages. "Somewhat" because economic dependency is included as if duty and filial ties, tradition and culture are insufficient. Cases in Fiji over the period 2007-2009 recognised the import of tradition, culture, duty and filial obeisance without the need for bolstering, with a nod to economic dependency, this context and reality of pressure as coercion or duress. ${ }^{135}$ After all, at 25 and having lived in Australia for some four years, $\mathrm{Mr}$ Nagri could have sought alternative employment. However, duty and filial ties, tradition and culture stood in the way of his doing so. Fiji decisions recognise this impact as, for example, in MIR and $N N J^{136}$ where the 31year-old applicant had lived overseas for ten years, returning to Fiji twice during that time. His mother demanded his acquiescence to an arranged marriage. He complied, leaving ahead of the traditional or religious wedding. Duress lay in duty, tradition, culture and filial obedience, where all his alternative supports and affiliations were abroad. His role as child to a widowed mother undermined his capacity to resist.

Rather than resort to economics, the impact of culture, tradition and religion on child-parent relations must be recognised fully. Underpinning parental dominance, these factors do not disappear when a child becomes adult. Inevitably, this raises a question as to Munby J's position in NS $v$ $M I$, reliant on Singer J's reference in $R e S K^{137}$ to arranged marriage.

\section{WHOSE CULTURE, WHOSE RIGHTS?}

In Re SK Singer J emphasised, saying it "always" needs to be emphasised, that forced marriage constitutes "a spectrum" ranging from "physical force" or "fear of injury or death in their most literal form", through to the "undue imposition of emotional pressure ... at the other end of the forced marriage range", however:

\footnotetext{
134 Ibid.

135 Set by the present author as CJ, nullity decisions have since followed this precedent.

${ }^{136}$ FamCas No 08/2007, 6 May 2008.

137 SK (An Adult)(Forced Marriage: Appropriate Relief)[2005] 3 All ER 421, [2004] EWHC 3202 (Fam).
} 
“... a grey area then separates unacceptable forced marriage and marriages arranged traditionally which are in no way to be condemned, but rather supported as a conventional concept in many societies. Social expectations can of themselves impose emotional pressure and the grey area to which I have referred is where one may slip into the other: arranged may become forced but forced is always different from arranged." 138

Yet being "supported as a conventional concept in many societies" cannot make arranged marriages fully and freely consenting. Conventional concepts, after all, can be damaging to those obliged to conform to them. Women's struggle throughout the ages, in all societies, to surmount patriarchy bears testament to the fact that convention is dictated by those in power: those lacking power are obliged to conform, or rebel.

Annual UN Commission on the Status of Women conferences confirm that women seek to renounce conventional concepts imposed by tradition, religion or culture, demanding that their respective societies accept women as human, with human rights and entitlements. Since the League of Nations, international treaties have affirmed women's struggle against conventions deemed acceptable by male-only and male-dominated parliaments and ruling bodies.

Singer $\mathrm{J}$ appears unmindful or unknowing of this struggle and its longevity. His obeisance to cultural diktats undermining women's autonomy is indicative of a thread extolling cultural difference at the expense of women's rights. This ignores, too, the ICESCR which, whilst affirming the importance of culture within societies simultaneously affirms the fundamental requirement that marriage must be a freely consented to relation.

Free consent is free consent to marriage -

- free consent of the parties, not free consent of the parents of the parties, and

- free consent to marriage, not "consent" to conform to culture or parental wishes.

Nullity cases time and again reveal that arranged marriages flout the "free consent to marriage" standard, despite lack of kidnapping, transportation to foreign soil, passport confiscation, threats of abuse

${ }^{138}$ Ibid [7]. 
against the child or someone else. The demand is for daughters (sometimes sons) to conform to culture, religion, tradition, duty and parental wishes. Daughters (sometimes sons) are obliged to "consent" to the marriage agreement we (your parents) make: "You'd better marry somebody we want you to ...”, to paraphrase Hirani.

The evidence in MPL $v$ JSG is telling. The father said that had he known of the prospective husband's drug problem, "consent would never have been given". ${ }^{139}$ The consent referred to is consent of the father to his daughter's marriage to another man's son. Any consent the daughter was asserted to have exercised would be "consent" to her father's wish that she marry the "partner" chosen by him. It is fanciful that free consent is given to marriage when parties have not met one another prior to arrival at the registry office, or have met only upon parental diktat. That culture says "meet at the registry office" (or on the wedding day, etc) cannot turn acquiescence into full and free consent to wed someone chosen and imposed by others.

In Fiji, many parents of Indian origin are concerned that their children contract marriage with foreign nationals - often originally from Fiji and holding Australian, Canadian or Aotearoa/New Zealand citizenship - by reason of the country's political situation. ${ }^{140}$ That parents generally wish the best for their children in these circumstances cannot oust the requirement of free consent to marry in real rather than fanciful terms or in real terms as to marriage, rather than as to "agreeing" with parental wishes. It cannot transform parents' agreement to a betrothal into the parties' consent to wed one another - freely.

This is not to impose Western cultural views of marriage upon persons whose origins lie in other cultures. It is to say that full and free consent or free consent to marry means just that: full and free or free consent to marry a person whom a marital partner has chosen freely, rather than culturally imposed "consent" by filial, religious or traditional duty to the consent of a parent to a marital arrangement. This distinction is clearly recognised in Sindh Province, where "arranged" marriage of the type Singer $\mathrm{J}$ sees as "marriages arranged traditionally which are in no way to be condemned, but rather supported ..." ${ }^{141}$ are condemned by state law. As the Sindh Child Marriage Restraint Act of 2013 provides:

"Under the law, any groom who weds a girl under age 18, and parents of such a groom or those facilitating such a marriage will

\footnotetext{
139 FHC Case No. 1182/2006 (15 February 2007) at 11.

140 See for example KKC and PSR (Case No: 12LBS0006 (1 March 2013).

141 SK (An Adult)(Forced Marriage: Appropriate Relief)[2005] 3 All ER 421, [2004] EWHC 3202 (Fam).
} 
be punished with maximum three years, minimum two years, rigorous imprisonment, and a fine”.

This is not simply about child marriage. It is about freedom to marry a partner of choice. So, returning to $N S v M I^{142}$ Munby J there spoke of stereotyping, citing his judgment in $\operatorname{Re} K$ :

"We must guard against the risk of stereotyping. We must be careful to ensure that our understandable concern to protect vulnerable children (or, indeed, vulnerable young adults) does not lead us to interfere inappropriately - and if inappropriately then unjustly - with families merely because they cleave, as this family does, to mores, to cultural beliefs, more or less different from what is familiar to those who view life from a purely Euro-centric perspective." 143

In elevating "families", Munby $\mathrm{J}$ fails to recognise that not only European countries adhere to the proposition that "full and free" consent to marriage is a matter for prospective marital partners, not for "families". International treaties and conventions - agreed to by nations way over and beyond those from Europe or with European connections - do not refer to "full and free" consent by families, nor place family before the woman (or man) whose agreement to marriage is the issue. Nor do European states or those with European connections alone recognise the right of prospective marriage partners - not their parents - to agree fully and freely to marriage. In seeking to be seen as culturally sensitive, $N S v M I$ and $R e K$ apply stereotypes placing in the forefront patriarchal notions of what is right and proper for children, giving imprimatur to parental rights recognised by international treaties and conventions as wrong.

142 [2006] EWHC 1646 (Fam).

143 Ibid [37]. 